\title{
Ecological and Economic Potentials of Cocoa Agroforestry Systems in the Center Region of Cameroon
}

\author{
Madountsap Tagnang Nadege ${ }^{1,}$, , Simo Claude ${ }^{1}$, Kabelong Banoho Louis-Paul Roger ${ }^{2,4}$, \\ Chimi Djomo Cedric ${ }^{2,3}$, Ntsefong Godswill Ntsomboh ${ }^{2,3}$, Ntonmen Amandine Flore Yonkeu ${ }^{2}$, \\ Tchinda Metagne Carole ${ }^{2}$, Tchoupou Votio Mireil ${ }^{2}$, Zapfack Louis ${ }^{2}$ \\ ${ }^{1}$ Department of Plant Biology, Faculty of Science, University of Douala, Cameroon \\ ${ }^{2}$ Department of Plant Biology, Faculty of Science, University of Yaounde, Cameroon \\ ${ }^{3}$ Institute of Agricultural Research for Development, Yaounde, Cameroon \\ ${ }^{4}$ International Union for Conservation of Nature and Natural Ressources, Yaounde, Cameroon
}

Email address:

madnadege@yahoo.fr (M. T. Nadège)

${ }^{*}$ Corresponding author

\section{To cite this article:}

Madountsap Tagnang Nadege, Simo Claude, Kabelong Banoho Louis-Paul Roger, Chimi Djomo Cedric, Ntsefong Godswill Ntsomboh, Ntonmen Amandine Flore Yonkeu, Tchinda Metagne Carole, Tchoupou Votio Mireil, Zapfack Louis. Ecological and Economic Potentials of Cocoa Agroforestry Systems in the Center Region of Cameroon. American Journal of Agriculture and Forestry.

Vol. 8, No. 5, 2020, pp. 214-222. doi: 10.11648/j.ajaf.20200805.15

Received: September 19, 2020; Accepted: October 5, 2020; Published: October 16, 2020

\begin{abstract}
Agroforestry especially in the context of cocoa production is a powerful tool for sustainable development. The overall objective of this study was to identify the type of cocoa Agroforestry System (CAS) that can conciliate ecological interests with existential concerns of rural populations. Characterization of the different types of CAS was done through a questionnaire survey of 140 cocoa farmers and field sampling in $25 \mathrm{~m}$ x $25 \mathrm{~m}$ quadrats where all trees of dbh $\geq 10 \mathrm{~cm}$ were inventoried. The undergrowth, the litter and the roots were collected respectively in quadrats of $1 \mathrm{~m}^{2} ; 0.5 \mathrm{~m}^{2} ;$ and $0.2 \mathrm{~m}^{2}$. A total of 122 quadrats were assessed in the different types of CAS in the study area. The results show that there are three types of CAS including Traditional, SODECAO and Innovative CAS. The most profitable CAS in terms of merchant cocoa are Innovative CAS $\left(2223.75 \$\right.$.ha $\left.^{-1}\right)$ followed by SODECAO CAS $\left(2014.61 \$ . \mathrm{ha}^{-1}\right)$. There is a significant difference $(\mathrm{p}<0.001)$

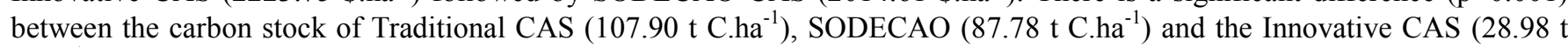
C.h $\left.{ }^{-1}\right)$. The SODECAO CAS is the most appropriate to conciliate cocoa farming and carbon sequestration.
\end{abstract}

Keywords: Cocoa Agroforestry System, Carbon Stock, Ecological Value, Economic Value, Cameroon

\section{Introduction}

Deforestation observed in many countries has the direct consequence of $\mathrm{CO}_{2}$ emission into the atmosphere [1]. This deforestation has contributed significantly to climate change, which remains to this day one of the major concerns of the international community and a reality which all of humanity must face [2]. For this purpose, several African countries including Cameroon through the adoption of REDD+have decided to reduce their greenhouse gas emissions linked to degradation and to deforestation [3]. Limiting deforestation does not only entail less carbon release into the atmosphere, but also enhanced preservation of habitat for many endangered species and the maintenance of essential ecological services [4-6]. That is why over the past decade, the need to reduce the harmful effects of climate change has created a need for information on the evolution in time and space of the vegetation cover. In order to define a global climate policy, reliable estimates of carbon stocks in forest ecosystems are necessary [7]. In this context, agroforestry is seen as an option for sustainable land use which both integrates the conservation of resources and provides livelihoods for the population [8]. These systems offer a range of services such as conservation of biodiversity and soil, maintenance of soil fertility and provision of additional resources to local populations while contributing to the gross 
domestic product (GDP) [9-11]. Carbon sequestration is also one of the ecosystem services rendered by these agroforestry systems [12-13]. The average carbon content of cocoa

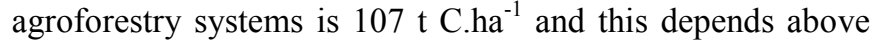
all on associated trees which contribute more than 95\% [14].

Cocoa farming plays a major role in the economy of the main African cocoa producing countries where this cocoa cultivation meets three objectives: to provide foreign monetary exchange to the country, to contribute to the state budget and to provide income to the rural populations who depend on it $[15-18,2]$. Indeed, agroforestry can be a powerful tool for sustainable development in disadvantaged areas $[19,20]$. It is estimated that 5 to 6 million smallholder farmers worldwide work on cocoa plantations and support around 40 to 50 million people [17]. Between 2014 and 2015, 4.2 million tons of cocoa worth about 12 billion USD have been produced worldwide with three-quarters grown in West Africa, $10 \%$ in Asia and the rest in South and Central America [21]. The cocoa sector in Cameroon represents about $2 \%$ of national GDP with primary GDP making $6 \%$ and about $30 \%$ of GDP from the agricultural sub-sector committed for export and transformation [21].

However, the cocoa value chain lacks sustainability. Producers often fail to break out of the vicious circle of low productivity and low income, lack of investment in their plantations and low yields. However, in several African countries, the sustainability of farms that contribute to livelihoods from cocoa production is threatened by the disappearance of forest land [22] Although the cocoa tree is considered a shade plant, its productivity increases when it is fully exposed to light [23-24]. In Cameroon, cocoa farming is based on several types of agroforestry systems [25], which suggests that a sustainable cocoa farming model based on agroforestry farming systems is possible. Faced with environmental problems and those relating to climate change, the main African cocoa producing countries are confronted with new challenges: maintaining or even increasing their level of production of merchant cocoa because of the place occupied by this raw material in their economy. There is need to stabilize the existing production areas in order to minimize the disappearance of forest areas linked to cocoa farming and thus reduce its negative impact on the environment ([26, 8]).

These new challenges therefore imply identifying the different types of CAS that exist in Cameroon in order to determine which one can conciliate ecological interests (ability to sequester carbon) with the existential concerns of rural populations (ability to generate income). The traditional or complex agroforest system which is the oldest of all, corresponds to the system where the cocoa trees are associated with many perennial, forest and fruit species, with multiple uses, thereby providing farmers with different products for sale or consumption [27, 13, 28]. These systems are found in Africa, America, Asia and Europe [29- 32]. The semi-improved system is a system that was implemented in the $1980 \mathrm{~s}$ by the Cocoa Development Corporation (SODECAO) where cocoa cultivation is done under managed forest $[18,1]$. Shading is recommended and the alternation between the cocoa trees and other fruit or forest species is 3 $\mathrm{m} \times 3 \mathrm{~m}[33,1]$. The alignment of the trees in this system makes it possible to have a homogeneous density per unit area, so that each tree has the same volume of useful soil and is subjected to the same light intensity required for its harmonious development $[34,35]$. The third type of so-called Innovative cocoa system is one where the technical model proposed to farmers by research and development experts favors the development of cocoa plantations under light shade, labour intensive and use of much chemical inputs: mineral fertilization, phytosanitary treatments [35].

Work to assess these systems is necessary to stabilize existing production areas in order to limit as much as possible the disappearance of forest areas linked to cocoa farming and thus reduce its negative impact on the environment. The present study is part of the approach that contributes on the one hand, to assess the financial profitability in terms of merchant cocoa from Traditional, SODECAO and Innovative CAS present in the Center Region of Cameroon, and on the other hand, to evaluate the financial profitability linked to the ecological value of carbon stocks in these CAS towards mitigation of climate change consequences and facilitation of the implementation of the REDD+process in Cameroon. Specifically, the study aimed at determining the type of CAS that best conciliates ecological interests with existential concerns of rural populations.

\section{Materials and Methods}

\subsection{Study Site}

The present study was conducted in the Center Region of Cameroon, specifically in the localities of Talba and Yambassa. Talba village is located in the Mbangassina Sub division in Mbam-et-Kim Division [36, 35]. Yambassa is a village in the Bokito Sub division of the Mbam-et-Inoubou Division. It is located between Balamba village and the city of Ombessa precisely on the national road $n^{\circ} 4$ (Yaoundé-ObalaBafoussam), $112 \mathrm{~km}$ north of Yaounde. In both localities soils are lateritic, sandy clay and rich in organic matter; it is appropriate for diversified agriculture. The soil morphology is formed by plains, plateaus and some hills [37]. The prevailing climate is of the Guinean equatorial type, characterized by four seasons of uneven distribution. The long rainy season runs from mid-August to mid-November, while the short rainy season runs from April to June. The long dry season is between mid-November and March and the short dry season between June and July [36]. The annual average temperatures oscillate between $22^{\circ} \mathrm{C}$ and $32^{\circ} \mathrm{C}$, with a thermal amplitude varying between $8^{\circ}$ and $13^{\circ} \mathrm{C}$. The rainfall is between 1300 and $1500 \mathrm{~mm}$ of water per year [38]. The Talba forest has become considerably impoverished due to the combined effects of industrial logging, artisanal logging and slash- andburn agriculture $[39,40]$. Yambassa is located in the vast area of peri-forest savannah with Sterculiaceae and Ulmaceae. Its fauna is originally very diverse, but remains an area of intensification of cultural practices [41]. 


\subsection{Data Collection Methods}

\subsubsection{Impact of Each Type of CAS on Revenues from the Merchant Cocoa}

This study was conducted between 2015 and 2016 in the CAS of Yambassa and Talba in the Center Region of Cameroon. The choice of these localities is mainly explained by the fact that they have neighboring ecologies (all located in the forest-savannah transition zone) and the choice of the study area was based on the presence of the types of CAS present in the site.

The characterization of CAS was done through structured and semi-structured interviews addressed to producers. To ensure that the targeted farmers were in a position to provide relevant answers to the questionnaires administered to them, the cocoa farmers' coordinators in the Mbangassina and Bokito districts ensured the presence of dynamic farmers in the agricultural sector who are open to innovations and have participated in one or more popularization activities on cocoa farming. Therefore, a total of 180 cocoa farmers were investigated in the study area, with 60 cocoa farmers having CAS Traditional types, 60 cocoa farmers having CAS Innovative types and 60 cocoa farmers having SODECAO CAS type $[42,43]$. This survey made it possible to assess the production of each cocoa farm for market cocoa. The CostBenefit Analysis method was used for the economic evaluation. It consisted of a comparison between costs and benefits over a given period. In the agricultural field, it requires access to information concerning the activities, flows and results of the operation. Also, during an agricultural season, one must necessarily collect all the information regarding the products (profits) and the charges (operating costs).

\subsubsection{Economic Evaluation}

\section{Assessment of Annual Operating Income}

Annual operating income is made up of gross annual income and annual net income. Gross annual income still includes annual operating expenses while annual net income does not. But before determining these revenues, it is necessary to determine the annual operating costs [44].

\subsubsection{Annual Operating Expenses}

Generally speaking, annual operating expenses are made up of annual functioning charges. Among these expenses are the installation and development costs which represent variable costs, operating costs, and depreciation. In fact, operating expenses can be broken down into several costs such as:

1. maintenance costs which include the costs associated with clearing, pruning, processing, picking and denting all assessed based on the wage labor exercised in the various plots, and on the various declarations of the producers. The workforce is sometimes evaluated either according to the number of working days, or according to the task performed.

2. costs of treatment, maintenance and phytosanitary products;

3. costs related to the transport of beans.

\subsubsection{Assessment of Carbon Stocks in the Different Types of $C A S$}

The sampling was carried out using the $25 \mathrm{~m} \times 25 \mathrm{~m}$ quadrats method [45], for a total of 120 quadrats constituting respectively 40 quadrats for each of the types of cocoa CAS. The biomass was estimated using the nondestructive method for the aboveground biomass and destructive for the hypogeum biomass. For each quadrat, individuals with a diameter at breast height $(\mathrm{dbh})$ greater than or equal to $10 \mathrm{~cm}$ were measured at $1.30 \mathrm{~m}$ from the ground and $0.30 \mathrm{~m}$ from the ground for cocoa trees. Within the $25 \mathrm{~m} \mathrm{x} 25 \mathrm{~m}$ quadrats (Figure 1), frames of $1 \mathrm{~m} \mathrm{x} 1 \mathrm{~m}$ were disposed at random for the collection of grass and the frames of $0.5 \mathrm{~m} \mathrm{x} 0.5 \mathrm{~m}$ inside of these for litter. As for the roots, they were dug from the $0.2 \mathrm{~m} \times 0.2 \mathrm{~m}$ quadrats to a depth of $20 \mathrm{~cm}$, then by the flotation method, they were picked up using a fine sieve and bagged.

Samples of species not identified in the field were collected, pressed in newspaper and kept with alcohol for identification by comparison with the specimens present at the National Herbarium of Cameroon.

\subsection{Data Analysis}

\subsubsection{Analysis of Economic Data}

The analysis of variance (ANOVA) was applied to the different variables studied and comparison of means (Annual Operating Charges, Annual net incomes, carbon stocks) between the different CAS zones study were carried out by the Tukey HSD test with a confidence interval of $5 \%$ using R 3.1.3 software.

The following formula proposed by [46] Gates and Gilly (1987) was used to calculate the Annual Operating Charges:

$$
\mathrm{AOC}=\mathrm{C}_{\mathrm{id}+} \mathrm{C}_{\text {exp }+} \mathrm{A}_{\mathrm{d}}
$$

Where $\mathrm{AOC}=$ total Annual Operating Charges.

$\mathrm{C}_{\mathrm{id}}=$ installation Charges and development costs.

$\mathrm{C}_{\mathrm{exp}}=$ operating Charges expenses;

$\mathrm{A}_{\mathrm{d}}=$ depreciation.

\subsubsection{Gross Annual Income}

The gross annual income takes into account the production of the plot (marketable cocoa). The Gross annual income was calculated by making the product of the annual production of each system by the price per kilogram of the quantities sold by the producers with the formula proposed by [47]:

$$
\mathrm{G}_{\text {cocoa }}=\mathrm{P}_{\text {cocoa }} \times \mathrm{Q}_{\text {sold }}
$$

Where: $\mathrm{G}_{\text {cocoa }}=$ gross annual income from cocoa;

$P_{\text {cocoa }}=$ price per kilogram of cocoa;

$\mathrm{Q}_{\text {sold }}=$ quantity sold by producers;

The price of the kilogram of marketable cocoa was calculated by averaging the prices declared by producers at all sites for the year concerned by the study. It has been estimated to average $1.98 \$ . \mathrm{kg}^{-1}$.

\subsubsection{Annual Net Income}

The annual net income (AN) was calculated by making the 
difference between the Gross annual income (GI) and the annual operating expenses (AOE) by system.

$$
\mathrm{ANI}=\mathrm{GI}-\mathrm{AOE}
$$

Where ANI = annual net income

$\mathrm{GAI}=$ gross annual income.

$\mathrm{AOE}=$ annual operating expenses.

\subsubsection{Estimation of Carbon Stock by Type of CAS}

Chave's equation [48] predicts the aerial biomass of trees in Africa. This equation takes into account the diameter of the tree, the density of the wood of the species and the climatic index; and therefore, remains the most recommended in the tropical zone. This equation made it possible to estimate the aboveground biomass of cocoa trees and associated trees. It is defined as follows:

Where:

AGB = aboveground biomass; $\mathrm{D}=$ diameter at breast height; $\rho=$ density of wood of the species; $E=$ Climate index.

The allometric equation developed by [49] was used for Elaeis guinensis such as:

$$
\mathrm{Y}(\mathrm{kg})=4.5+7.7 * \mathrm{H}
$$

Where $\mathrm{Y}=$ biomass; $\mathrm{H}=$ height.

The aboveground biomass values obtained in each $625 \mathrm{~m}^{2}$ plot and those of other carbon pools were extrapolated per hectare using an expansion factor (EF) $F E=$ $10.000 \mathrm{~m}^{2} /$ plot area $\left(\mathrm{m}^{2}\right)$ [7].

The total biomass estimated from this equation is then converted into the corresponding sequestered carbon stock by multiplying it by 0.47 [50].

\subsubsection{Ecological Value or Economic Profitability of Carbon}

This ecological value being the value of carbon if it is sold on the market. In fact, within the framework of this study, the ecological value is the financial value on the market deducted from the carbon stock sequestered by all the listed species. This value likely to be generated in the event of payment for Ecosystem Services (PES) to CAS through the sequestration of atmospheric $\mathrm{CO}_{2}$ can have an economic or monetary equivalent according to regulated markets such as the Clean Development Mechanism (CDM) and REDD+or voluntary markets (Anonymous, 2013). Average carbon stocks have been converted into ecological value as recommended by the carbon market in REDD+to obtain Reduced Emissions Certificates (CERs) which will be translated into equivalent tonnes of $\mathrm{CO}_{2}$ which is the currency of exchange for the carbon market, by applying a value of $8 \$$ per unit of equivalent tonne of sequestered $\mathrm{CO}_{2}$, thus, $1 \mathrm{CER}=8 \$[51]$.

\section{Results}

\subsection{Assessment of Annual Operating Expenses (\$.ha ${ }^{-1}$ year ${ }^{-1}$ )}

The annual operating costs of the three types of CAS in the study area are made up of the cost of phytosanitary treatments, the cost of labor for manual weeding and the cost of tools (Figure 2). There is no significant difference between the annual expenses of the different CAS $(\mathrm{p}<0.000)$. In fact, the largest value was obtained in Traditional CAS (683.96 $\left.\$ . \mathrm{ha}^{-1}\right)$. These values are decreasing without being significantly different $(\mathrm{p}>0.05)$ from Traditional CAS to SODECAO CAS (567.78 \$.ha ${ }^{-1}$ ) and Innovative CAS (509.05 \$.ha $\left.{ }^{-1}\right)$.

\subsection{Assessment of Annual Net Income by Type of CAS $\left(\$ . h a^{-1} \cdot\right.$ year $\left.^{-1}\right)$}

There is a significant difference between the annual net income of different cocoa CAS $(p<0.001)$. The greatest value was obtained in Innovative CAS (2223.75 \$.ha $\left.{ }^{-1}\right)$. The net annual income decreases without being significantly different from Innovative CAS towards SODECAO CAS (2014.61 \$.ha $\left.{ }^{1}\right)$. However, there is not only a significant difference between the annual net income of Innovative cocoa CAS and that of Traditional cocoa CAS (380.38 \$.ha $\left.{ }^{-1}\right)$, but also, a significant difference between the annual net income of SODECAO CAS and those of Traditional CAS (Figure 3).

\subsection{Assessment of Annual Capital Productivity by Type of System}

The evaluation of the annual productivity of capital by type of system measures the efficiency of each type of CAS and is obtained by reporting the Annual Net Income on the Annual Operating Costs. It appears that there is not only a significant difference $(\mathrm{p}<0.001)$ between the annual productivity of Innovative CAS (4.37) and that of Traditional CAS (0.56), but also, a significant difference between the annual productivity of SODECAO CAS (3.55) and that of Traditional CAS. On the other hand, there is no significant difference between the annual productivity of Innovative CAS and that of SODECAO CAS (Table 1).

\subsection{Total Amount of Carbon Stored by Each Type of Cocoa Agroforestry System}

Figure 4 shows the total amount of carbon stored by each type of cocoa agroforest system. The results of the ANOVA test $(\mathrm{p}<0.001)$ show that there is a significant difference between the carbon stock of Traditional CAS (107.90 t C.ha' $\left.{ }^{1}\right)$, SODECAO (87.78 t C.ha $\left.{ }^{-1}\right)$ and that of Innovative CAS

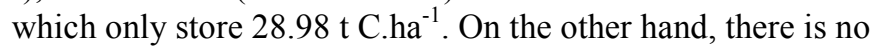
significant difference between the carbon stock of Traditional CAS and that of SODECAO CAS.

\subsection{Comparison Between Ecological Carbon Values and Commercial Values of Merchant Cocoa from the Different CAS in the Study Area}

The ecological value (EV) of carbon and the commercial value (VC) of different cocoa CAS are recorded in table 2. This shows that the ecological value of carbon is higher in Traditional CAS (863.2 \$.ha $\left.{ }^{-1}\right)$ than in SODECAO (702.32 $\left.\$ . \mathrm{ha}^{-1}\right)$ and Innovative (231.84 $\left.\$ . \mathrm{ha}^{-1}\right)$. Similarly, the 
ecological value of carbon is higher in SODECAO CAS than in Innovative CAS. However, we notice that the commercial value of merchant cocoa decreases successively from Innovative CAS $\left(2732.80 \$ . \mathrm{ha}^{-1}\right)$ to the SODECAO CAS (2582.39 \$.ha $\left.{ }^{-1}\right)$ and Traditional CAS (1064.39 \$.ha' $\left.{ }^{-1}\right)$.

\section{Discussion}

\subsection{Does the Type of CAS Impact Income from Marketable Cocoa}

Cocoa farming is the main activity of the population, and the management methods of agroforests vary according to the type of CAS. Three main types of CAS are encountered in the study area:

Traditional CAS offers a range of services such as biodiversity conservation, maintaining soil fertility ([52, 17, 11]). The plant material used in this type of system is improved, which contributes to lower Net Income in merchant cocoa. In addition, the improvement of plant material which requires a considerable reduction in shade leads to the disappearance of the complexity of Traditional CAS [22]. As a result, we are witnessing the emergence of the SODECAO or semi-improved type of CAS where the plant material used is improved and makes it possible to boost the net income from marketable cocoa yield [22]. The so-called Innovative CAS is a system that is done under light shade [35]. This model which makes it possible to obtain high cocoa yields during the first years of cocoa exploitation, is adopted by a good number of farmers, particularly in Côte d'Ivoire $([30,53])$. The most profitable CAS in terms of marketable cocoa and capital productivity are those of Innovative CAS and SODECAO. These results could be explained by the presence of improved plant material used in these two types of CAS, showing that the economic performance of cocoa CAS depends on the type of plant material used [37]. The low Annual Income obtained in Traditional CAS could also be explained by a drop in production due to the aging of cocoa CAS and the high costs of farm charges for rehabilitation $([33,22])$. These results corroborate those of [54] and those of [25] who showed that the yield of marketable cocoa is higher when it is in light shade or even in monoculture. However, [24] had already specified that when cocoa farming is done under light shade, the yield decrease is progressive, because the cocoa plants exposed in full sun weaken quickly, thus causing a drop in the production regime and the shortening of its life cycle. This implies that the Innovative type of CAS, although very profitable in terms of merchant cocoa in the first years, could be questionable in the long run and as a means of sustainable development.

\subsection{Contribution of Each Type of CAS in the Sequestration of Carbon}

The absence of any significant difference observed between the carbon stocks of Traditional CAS and SODECAO could be explained by the fact that the woody biodiversity and the structure of these two types of CAS influence their carbon storage capacity [55] compared to that of Innovative CAS. Species introduced in Innovative CAS have a low potential for sequestration of carbon due to the intensification of cocoa. This result also suggests that in Innovative CAS, farmers maximize cocoa production to the detriment of shade trees resulting in a significant loss of carbon stocks [56]. Indeed, the quantity of carbon stored $\left(87.78 \mathrm{t} \mathrm{C}^{-h^{-1}}\right.$ ) by SODECAO CAS is similar to the $88.52 \mathrm{t}$ C.ha ${ }^{-1}$ obtained by [57] in the fallows of the ecological zones of Ghana, and the $70 \mathrm{t} \mathrm{C} \cdot \mathrm{ha}^{-1}$ obtained in the forest zones of the Central and South Cameroon Regions by [27]. However, this carbon stock remains higher than the $41.3 \mathrm{t} \mathrm{C}^{-h^{-1}}$ obtained by [58] in the savannas of South Africa and the 63.9 t C.ha ${ }^{-1}$ of [59] in the agrosystems of Ethiopia. Similarly, the amount of carbon stored in Traditional CAS (107.90 t C.ha ${ }^{-1}$ ) is similar to the amounts of carbon stored in certain plant groups in the forests of East Cameroon $\left(107.5 \mathrm{t} \mathrm{C} . \mathrm{ha}^{-1}\right)$ found by [49] and those of [32] in Ghana's CAS $\left(104 \mathrm{t} \mathrm{C}^{-1} \mathrm{ha}^{-1}\right)$. The carbon stocks obtained in the three types of cocoa CAS thus shows that the quantities of carbon stored depend on the type of cocoa CAS implemented as well as the environmental conditions which prevail there. This also implies that Traditional CAS and SODECAO contribute best to the fight against climate change $([5,1]$ compared to Innovative CAS.

\subsection{Ecological and Commercial Value of Different CAS of the Study Area}

Investigations and assessment of carbon stocks have made it possible to understand that cocoa CAS are composed of plant species that can sequestrate a significant amount of $\mathrm{CO}_{2}$ through photosynthesis [18]. Thus, apart from the sale of cocoa beans, these cocoa CAS could provide farmers with additional income from the sale of sequestrated carbon [10]; However, the ecological value of carbon obtained in Traditional CAS and SODECAO are three times higher than that obtained in Innovative CAS. This suggests that REDD+policies should be prioritized for Traditional CAS and SODECAO which sequestrate more carbon and play an important role in the long term stability and resilience of the ecosystem. Therefore, they can be considered the most suitable in the fight against climate change $([18,12])$. On the other hand, the fact that the ecological value is higher in Traditional CAS and SODECAO does not imply the abandonment of cocoa farming in favor of carbon sequestration, but rather shows that the sale of carbon could be a source of diversification of fairly consistent and sustainable income for cocoa farmers [13]. The commercial value of cocoa found in Innovative and SODECAO CAS is almost twice as high as that obtained in Traditional CAS. This could be justified by the fact that producers of SODECAO and Innovative CAS are more receptive to the innovations brought to cocoa farming compared to those of Traditional CAS. Given the importance of CAS relative to farmers' household income and in carbon sequestration, it is imperative, in the interests of sustainable management, ecological intensification and environmental protection, to 
reconcile cocoa farming and carbon sequestration. In this context, the SODECAO CAS could be the most appropriate given their performance in commercial cocoa production and carbon sequestration.

\section{Conclusion}

The CAS are an important means of poverty reduction and development support, particularly rural development where it has witnessed remarkable expansion. Indeed, the higher ecological value of carbon in Traditional and SODECAO CAS makes it possible to understand the ecological role of these types of cocoa CAS. This also shows that the Traditional and SODECAO CAS are valuable especially in an extent that they are able to sequestrate large amounts of carbon thereby limiting the impacts of climate change. The results obtained in Innovative CAS have shown that the carbon storage potential is incompatible with the intensification of cocoa farming. In addition, if it is necessary to reconcile carbon storage and performance of marketable cocoa yields, SODECAO CAS are the most suitable. Indeed, the REDD+mechanism implemented in the United Nations Framework Convention on Climate Change (UNFCCC) should allow developing countries to benefit from reducing their deforestation, forest degradation, increasing their forest carbon stocks and the conservation of their forests. Agroforestry systems could then benefit from this mechanism, given that carbon storage in cocoa based agroforests is now recognized and even quantified.

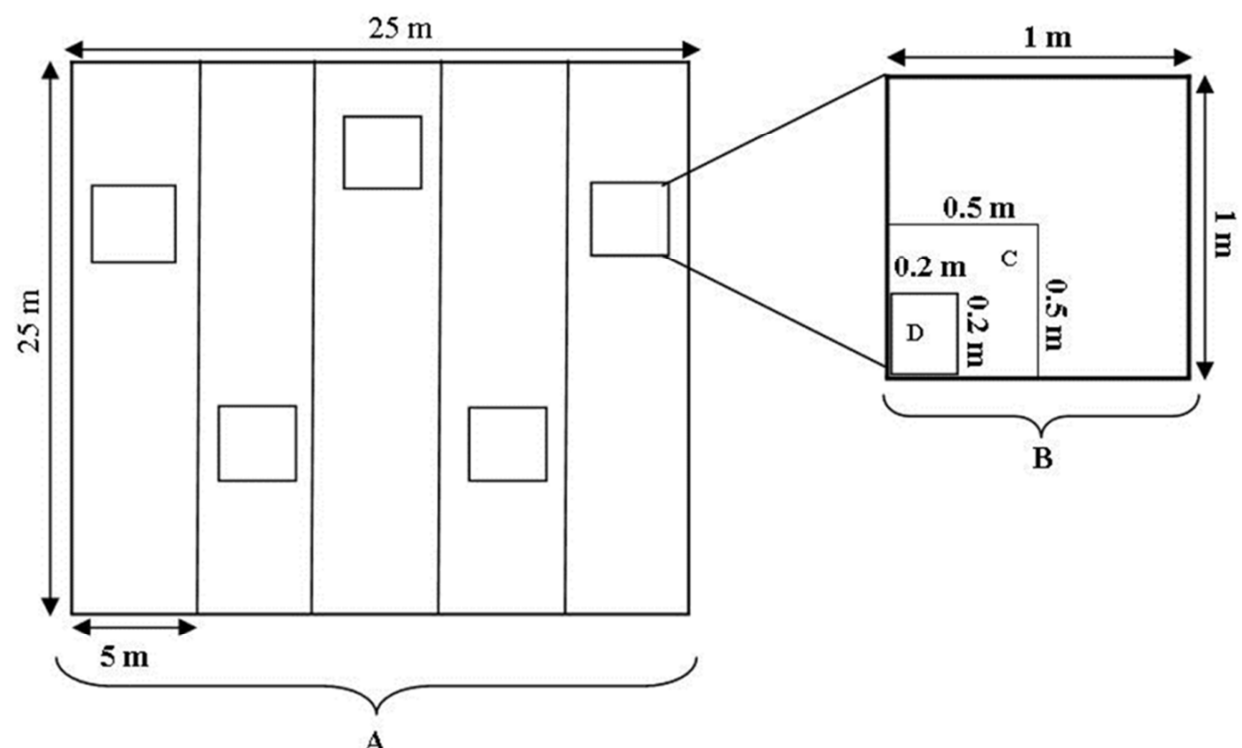

Figure 1. Experimental design for estimating the carbon stock sequestrated by each type of CAS. Inventory of species with DBH $\geq 10$ cm on survey plots of 25 $m \times 25 m(A)$, plots of $1 m \times 1 m$ to evaluate the biomass of the herbaceous plant (B), the biomass of the litter was evaluated in a plot of $0.5 m \times 0.5 m(C)$, and root biomass in $0.2 \mathrm{~m} \times 0.2 \mathrm{~m}(\mathrm{D})$ plots.

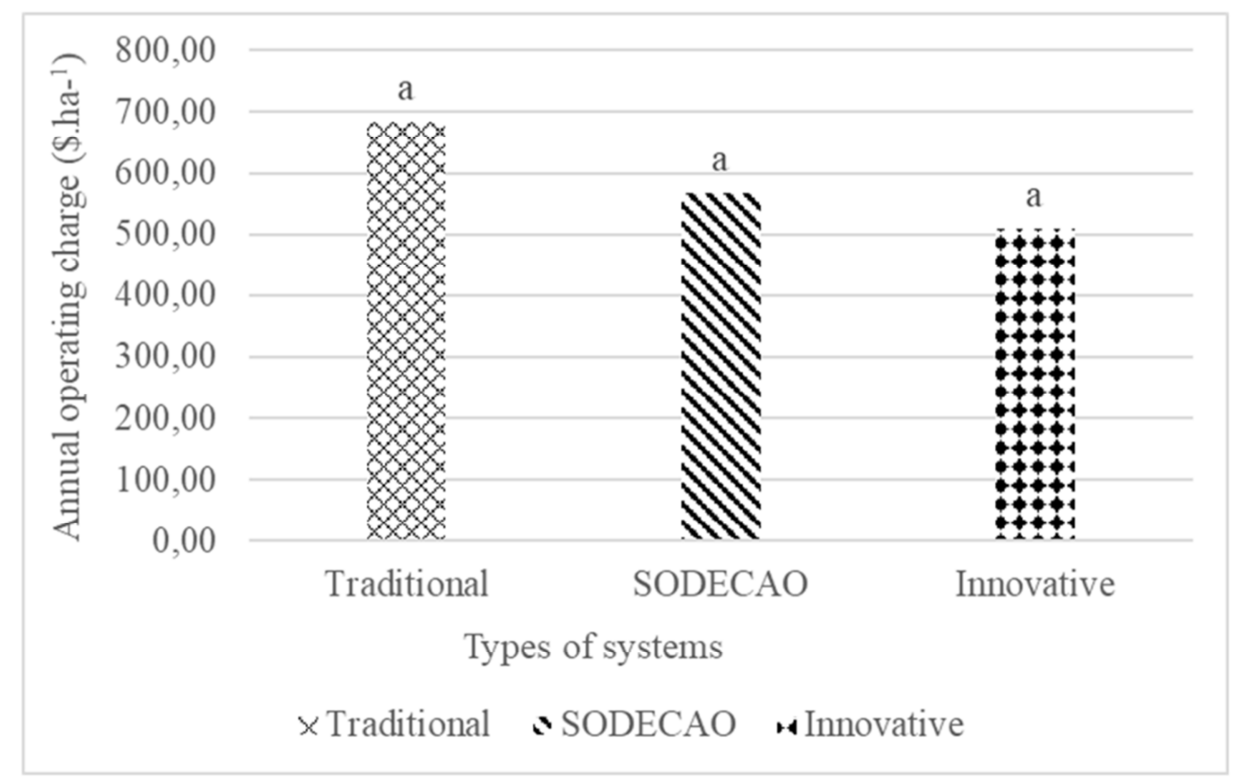

Figure 2. Annual operating charge by type of cocoa system. 


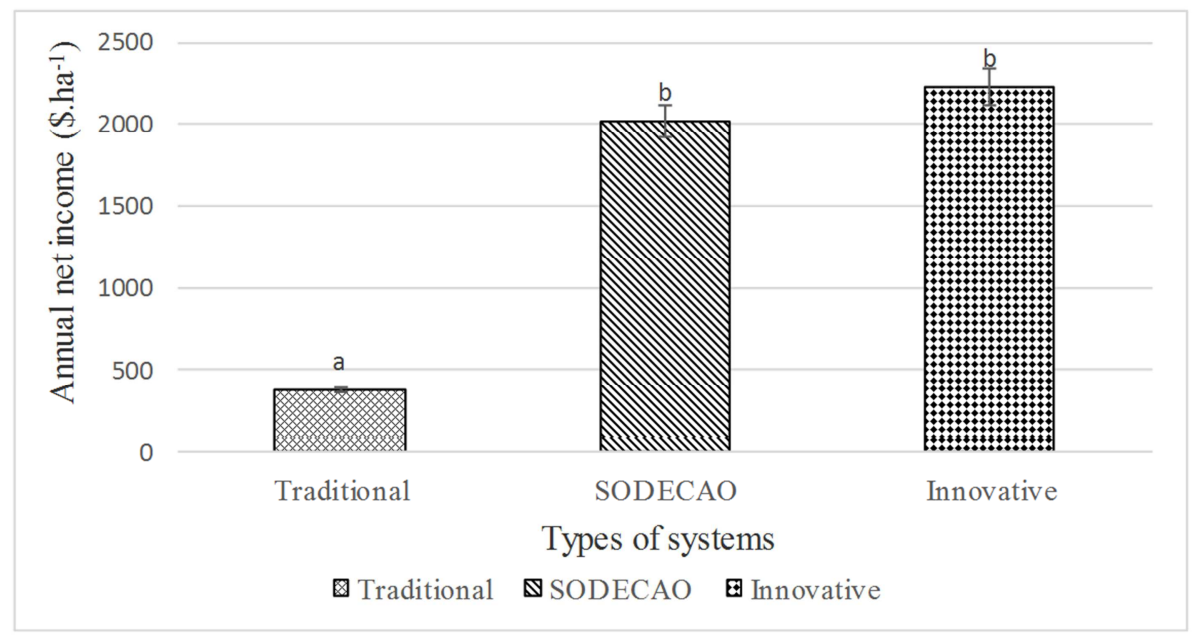

Figure 3. Assessment of Annual Net Income $\left(\$ . h a^{-1} \cdot\right.$ year $\left.{ }^{-1}\right)$ by type of CAS.

Table 1. Capital productivity by type of CAS.

\begin{tabular}{lllll}
\hline Types of systems & Annual charge (\$) & Gross Annual Income (\$) & Annual Net Income (\$) & Productive capital \\
\hline Traditional & $683.96^{\mathrm{a}}$ & $1064.39^{\mathrm{a}}$ & $380.38^{\mathrm{a}}$ & $0.56^{\mathrm{a}}$ \\
SODECAO & $567.78^{\mathrm{a}}$ & $2582.39^{\mathrm{b}}$ & $2014.61^{\mathrm{b}}$ & $3.55^{\mathrm{b}}$ \\
Innovative & $509.05^{\mathrm{a}}$ & $2732.80^{\mathrm{b}}$ & $2223.75^{\mathrm{b}}$ & $4.37^{\mathrm{b}}$ \\
\hline
\end{tabular}

Table 2. Comparison between ecological value of carbon and commercial value of merchant cocoa in each type of CAS in the study area.

\begin{tabular}{|c|c|c|c|}
\hline Types of systems & Carbon stock (t C.ha $\left.{ }^{-1}\right)$ & Ecological carbon value $\left(\$\right.$. ha $\left.^{-1}\right)$ & Commercial value of cocoa $\left(\$ . h a^{-1}\right)$ \\
\hline Innovative & 28.98 & 231.84 & 2.732 .80 \\
\hline SODECAO & 87.79 & 702.32 & 2.582 .39 \\
\hline Traditional & 107.90 & 863.2 & 1064.39 \\
\hline
\end{tabular}

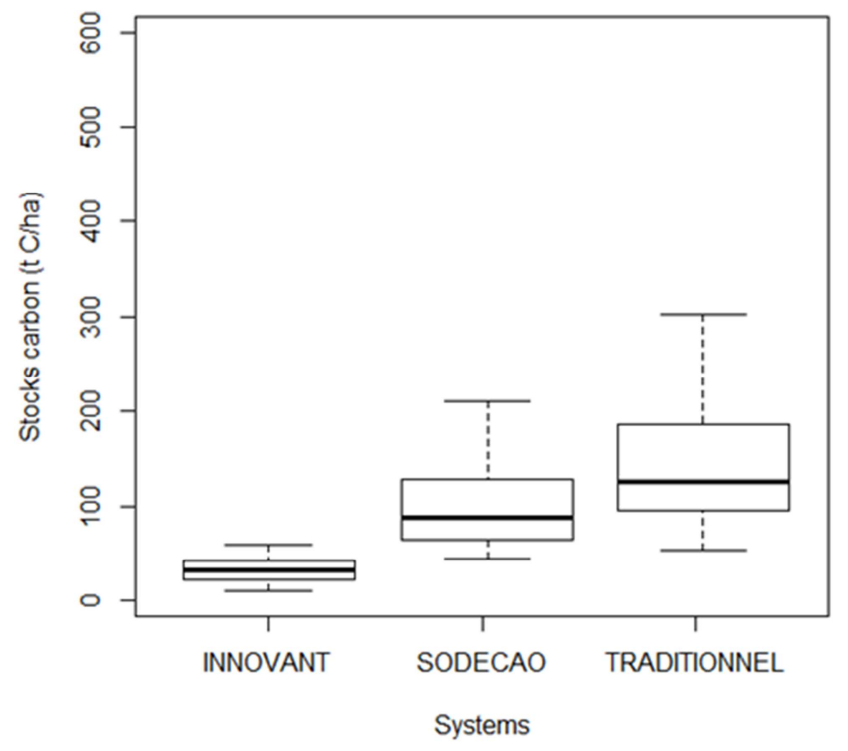

Figure 4. Total carbon stock stored by each type of cocoa agroforestry system.

\section{References}

[1] Madountsap T. N, Zapfack L, Chimi D. C, Kabelong BLP, Tsopmejio T. I, Forbi P. F, Nasang J. M. 2017. Biodiversity and carbon stock in the SODECAO agroforestry system of center region of Cameroon: Case of talba locality. American Journal of Agriculture and Forestry, 5 (4), 121-129.
[2] Dawoe E., Asante W., Acheampong E., Bosu P., 2016. Shade tree diversity and aboveground carbon stocks in theobroma cacao agroforestry systems: Implications for REDD+implementation in a West African cacao landscape. Carbon Balance and Management, 11, 1069. doi: 10.1186/s13021-016-0061-x.

[3] Newell R, Stavins R., 2000. Climate change and forest sinks: Factors affecting the costs of carbon sequestration. Journal of Environmental Economics and Management, 40 (3): 211-235.

[4] Fayolle A., Doucet J-L., Gillet J-F, Bourland N., Lejeune, P., 2013. Tree allome-try in Central Africa: Testing the validity of pantropical multi-species allometric equations for estimating biomass and carbon stocks. Forest Ecology and Management, $305,29-37$.

[5] Zapfack L., Chimi D. C., Noiha N. V., Zekeng J. C., Meyanya D. G. R., Tabue M. R. B., 2016. Correlation between associated trees, cocoa trees and carbon stocks potential in cocoa agroforests of Southern Cameroon. Sustainability in Environment. Vol. 1. $\mathrm{N}^{\circ} 2$.

[6] Kabelong B. L. P. R., Zapfack L., Weladji R. B, Djomo C. C., Nyako M. C., Bocko Y. E., Essono D. M., Nasang J. M, Tagnang N. M., Abessolo C. I. M., Sakouma K. R. M., Souahibou F. M., Palla F. J. S., Peguy T. K., Jiagho R., Kenmou T. L, Jumo U. A. C. K., Yi Andjik B. A. A., Mbobda R. B. T., 2018. Floristic diversity and carbon stocks in the periphery of Deng-Deng National Park, Eastern Cameroon. Journal of Forest Reseach. https://doi.org/10.1007/s11676-018-0839-7.

[7] Brown S., Pearson T., 2005. Exploration du potentiel de séquestration du carbone dans les forêts classées de la République de Guinée. Arlington: Winrock International. 39 p. 
[8] Torquebiau E., 2007. L'Agroforesterie. Des arbres et des champs. (Eds). L'Harmattan. Paris, France, 153 p.

[9] Malézieux E., 2011. Designing cropping systems from nature. Agronomy for Sustainable Development, 32, 15-29.

[10] Sonwa D. J., Weise S. F., Gotz S. M., Janssens J. J., HowardYana S., 2014. Plant diversity management in cocoa agroforestry systems in West central Africa: effects of markets and households needs. Agroforestry systems. DOI 10. 1007/s10457-014-9714-5.

[11] Madountsap T. N., Zapfack L., Chimi D. C., Kabelong B. L. P., Tsopmejio T. I., Tajeukem V. C., Forbi P. F., Ntonmen Y. A. F., Nasang J. M., 2018. Carbon storage potential of cacao agroforestry systems of different age and management intensity. Climate and Development, DOI: 10.1080/17565529.2018.1456895.

[12] Norgrove L., Hauser S. 2013. Carbon stocks in shaded Theobroma cacao farms and adjacent secondary forests of similar age in Cameroon. Tropical Ecological, 54: 15-22.

[13] Saj S., Jagoret P., Todem N. H., 2013. Carbon storage and density dynamics of associated trees in three contrasting Theobroma cacao agroforests of Central Cameroon. Agroforestry Systems, 87: 1309-1320.

[14] Temgoua L. F., Dongmo W., Nguimdo V., Nguena C., 2018. Diversité Ligneuse et Stock de Carbone des Systèmes Agroforestiers à base de Cacaoyers à l'Est Cameroun: Cas de la Forêt d'Enseignement et de Recherche de l'Université de Dschang. J. Appl. Biosci. 122: 12274-12286.

[15] Tim M., 2007. Principes d'agroforesterie. Durrance, Myers, 12: 17391-33917.

[16] Morgan J. A., Follett R. F., Allen L. H., Del Grosso S., Derner J. S., Dijkstra F., Franzluebbers A., Fry R., Paustian K., Schoeneberger M., 2010. Carbon sequestration in agricultural lands of the United States. Journal of Soil and Water Conservation, 65: 6-13.

[17] Gockowski J., Sonwa D., 2011. Cocoa intensification scenarios and their predicted impact on $\mathrm{CO}_{2}$ emissions, biodiversity conservation, and rural livelihoods in the Guinea rain forest of West Africa. Environmental Management, 48, 307-321.

[18] Sonwa D. J., Weise S. F., Nkongmeneck B. A., Tchatat M., Janssens M. J. J., 2017. Structure and composition of cocoa agroforests in the humid forest zone of Southern Cameroon. Agroforestry Systems, 91, 451-470.

[19] Nair P. K. R., 2007. The Coming of Age of Agroforestry. Journal of Sciences Food and Agriculture, 87: 1613-1619.

[20] Rusu E., 2013. The current situation of the stock of carbon in forest ecosystems at regional and global. Environment and Sustainable Development, 7 (1), 88-101.

[21] Friedel H., Claudia H., Irene K., Pedro M., Mara M., 2016. Renforcer la compétitivité de la production de cacao et augmenter le revenu des producteurs de cacao en Afrique de l'Ouest et en Afrique centrale. 53113, Bonn, Germany, 174 p.

[22] Lachenaud P., Oliver G., 1998. Influence d'éclaircies sur les rendements de cacaoyers. Plantation Recherche Développement, 5: 34-40.

[23] Braudeau J., 1969. Le cacaoyer. Collection Techniques agricoles et productions tropicales. Paris, France, Maisonneuve et Larose, $304 \mathrm{p}$.

[24] Mossu G., 1990. Le cacaoyer. Le technicien d'agriculture tropicale. Volume 14. Éditions Maisonneuve et Larose, Paris, $160 \mathrm{p}$.

[25] Jagoret P., Michel-Dounias I., Snoeck D., Todem N. H, Malézieux E., 2012. Afforestation of savannah with cocoa agroforestry systems: A small-farmer innovation in central Cameroon. Agroforestry Systems, 86, 493-504.

[26] Dixon J., Gulliver A., Gibbon D., 2001. Farming Systems and Poverty. Improving farmers livehoods in a changing world. Fao, Rome.

[27] Sonwa D. J., Weise S. F., Janssens M. J. J., 2002. Etude de cas d'aménagement forestier exemplaire en Afrique Centrale: les systèmes agroforestiers cacaoyers Cameroun. In FAO Départements des forêts. Document de travail FM/12F FAO, Rome, Italie, 49 p.

[28] Jagoret P., Michel I., Ngnogué T. H, Lachenaud P., Snoeck D., \& Malézieux E., 2017. Structural characteristics determine productivity in complex cocoa agroforestry systems. Agronomy for Sustainable Development, 37, 60. doi: 10.1007/s13593-017-0468-0.

[29] Salgado-Mora M. G., Ibarra-Nu'ñez G., Maci'as-Sa'mano J. E., Lo'pez-Ba'ez O., 2007. Diversidad arbo'rea en cacaotales des Soconusco, Chiapas, Me'xico. Interciencia, 32: 763-768.

[30] Ruf F., Schroth G., 2004. Chocolate forests and monocultures: A historical review of cocoa growing and its conflicting role in tropical deforestation and forest conservation. In G. Schroth G. A. B. da Fonseca C. A. Harvey C., Gascon H. L, Vasconcelos A. M. N. Izac (Eds.), Agroforestry and biodiversity conservation in tropical landscapes (pp. 107134). Washington, DC: Island Press.

[31] Juhrbandt J., Duwe T., Barkmann J., Gerold G., Marggraf R., 2010. Structure and management of cocoa agroforestry systems in Central Sulawesi across an intensification gradient. In: Tropical rainforests and agroforests under global change. Ecological and socioeconomic valuations. Tscharntke T., Leuschner C., Veldkamp E., Faust H., Guhardja E., Bidin A. (eds). Dordrecht, Pays-Bas, Springer: 115-140.

[32] Asare A., Tetteh D. A., 2010. The role of complex agroforestry systems in the conservation of forest tree diversity and structure in southeastern Ghana. Agroforestry Systems, 79: 355-368.

[33] Valet F., Berry D., 1997. Réforme des institutions dans les filières café-cacao au Cameroun. Chronique des années 1990 à 1997. CIRAD-SAR, Document N 11 , Montpellier, France. http://www.iucnredlist.org/search.

[34] Mbondji P., 2010. Le cacaoyer au Cameroun. Yaoundé: Presse de l'université catholique d'Afrique Centrale, Cameroun. 254 p.

[35] Ngono F., Mala A. W., Levang P., Ambang Z., 2015. Evolution des systèmes agroforestiers cacao et impact environnemental à Mbangassina: cas du village Talba. Revue Scientifique et Technique Forêt et Environnement du Bassin du Congo, 5, $62-67$.

[36] Ndoumbè M., 2003. Impact of removing disease pods on cocoa black pod caused by Phythopththora megakarya and on cocoa production in Cameroon. Crop Protection, 23: 415-424. 
[37] Pédelahore P., 2014. Farmers 'accumulation strategies and agroforestry systems intensification: The example of cocoa in the Central region of Cameroon over the 1910-2010.

[38] Jiofack T., Guedje N. M., Tchoundjeu Z., Fokunang C., Lejoly J., Kemeuze V., 2013. Agroforestry typology of some cocoa based agroforests in the Mbam and Inoubou division: The importance for local population livelihoods. Journal of Ecology and the Natural Environment, 5 (12): 378-386.

[39] Santoir C., Bopda A., 1995. Atlas régional Sud-Cameroun. Editions de l'Orstom Paris, France, 53 p.

[40] Elong J. G., 2016. Éton et Manguissa, de la Lékié au Mbamet-Kim: jeux et enjeux fonciers (Centre-Cameroun). Douala, Cameroun: Les Cahiers d'Outre-Mer. 18p.

[41] Letouzey R., 1968. Etude phytogéographique du Cameroun. Lechevalier, Paris, 511p.

[42] Bara G., Schoonmaker K. F., 1991. Introduction à la méthode accélérée de recherche participative (MARP): quelques notes pour appuyer une formation pratique 2ème Ed. International Institute for Environment and Development. Suitainable Agriculture Programme, Rome, 1-70.

[43] Beaud S., Weber F., 2003. Guide de l'enquête de terrain. Ed. La Découverte, Paris, 357 p.

[44] Nji A., Tchakoa J., 2000. Analyse des projets. Programme d'Enseignement à distance. Dschang, Cameroun. $30 \mathrm{p}$.

[45] Noiha N. V., Zapfack L., Mbade L. F., 2015. Biodiversity management and plant dynamic in a cocoa agroforest (Cameroon). International Journal of Plant \& Soil Science, 6 (2), 101-108.

[46] Gates J. \& Gilly B., 1987. Un modèle analytique d'aide à la décision en aquaculture. Archimer, Paris, $92 \mathrm{p}$.

[47] Alary V., 1996. Incertitude et prise de risque en période d'ajustement: Le comportement des producteurs de cacao du Cameroun avant et après 1994. Doctorat, Université de Paris 1, Sorbone, $749 \mathrm{p}$.

[48] Chave J., Ejou-Mechain R. M, Urquez B. A, Chidumayo E., Colgan S. M, Delitti W. B. C., Duque A., Eid T., Fearnside P. M., Goodman C. R., Henry M., Martinez-Yrizar A., Mugasha A. W, Muller- Landau C. H., Mencuccini M., Nelson B. W, Ngomanda A., Nogueira E. M., Ortiz-Malavassi E., El Pelissier R., Ploton P., Ryan C. M., Saldarriaga J. G., Vieilledent G., 2014. Improved allometric models to estimate the aboveground biomass of tropical trees. Global Change Biology, 10 (12629), 48 p.

[49] Cummings D., Boone K. J., Perry D., Hughes R., 2002.
Aboveground biomass and structure of rainforests in the southwestern Brazilian Amazon. Forest Ecology and Management, 163, 293-307.

[50] Zapfack L., Noiha N. V., Dziedjou K. P. J., Zemagho L., Fomete N. T., 2013. Deforestation and carbon stocks in the surroundings of Lobeké National Parc (Cameroon) in Congo Basin. Environment and natural Resources Research, 3 (2): 19.

[51] Héraud B., 2015. Cop 21: $8 €$ le prix de la tonne de carbone sur le marché européen. Novethic, 1-3.

[52] Schroth G., Harvey C. A., 2007. Biodiversity conservation in cocoa production landscapes: na overview. Biodiversity and Conservation springer, 16 (8): 2237-2244.

[53] Gockowski J., Afari-Sefa V., Sarpong B. D. Y. B., Osei-Asare B. Y, Fredua A. F. N., 2013. Improving the productivity and income of Ghanaian cocoa farmers while maintaining environmental services: What role for certification. International Journal of Agricultural, 11 (4), 331-346.

[54] Sonwa D. J, Weise S. F., Tchatat M., Nkongmeneck B. A., Adesina A. A., Ndoye O., Gockowski J., 2001. The role of cocoa agroforests in rural and community forestry in Southern Cameroon. Rural Development Forestry Network, $10 \mathrm{p}$.

[55] Somarriba E., Cerda R., Orozco L., Cifuences M., Davila H., Espin T., Mavisoy H., Avila G., Alvarado E., Poveda V., Astorga C., Say E., Deheuvels O., 2013. Carbon stocks and cocoa yields in agroforestry systems of Central America. Agriculture, Ecosystems and Environment, 173, 46-57.

[56] Kotto-Same J., Woomer P. L., Moukam A., Zapfack L., 1997. Carbon dynamics in slash and burn agriculture and land use alternative in the humid forest zone in Cameroon. Agriculture Ecosystems Environment, 65: 245-256.

[57] Adu-Bredu S., Abekoe M. K., Tachie-Obeng E., Tschakert P., 2011. Carbon stock under four land use systems in tree varied ecological zones in Ghana Constant. Forestry Reseach Institute of Ghana (FORIG), Kumasi, Ghana. 9 p.

[58] Manley R. J., Ickowicz A., Masse D., Floret C., Richard D., Feller C., 2004. Spatial carbon, nitrogen and phosphorus budget in a village of the west Africa Savanna-I. Element pools and structure of a mixed-farming system. Agricultural systems, 79: 55-81.

[59] Solomon D., Fritzsche F., Lehman J., Tekalign M., Zech W., 2002. Soil organic matter dynamics in the sub-humid agroecosystems of Ethiopian Highlands: Evidence from natural 13 $\mathrm{C}$ abundance and particle size fractionation. Soil Sciences Society of America Journal, 66: 969-978. 